\title{
THE EFFECTS OF VASOPRESSIN ON ACUTE KIDNEY INJURY IN
}

\section{SEPTIC SHOCK}

Anthony C. Gordon ${ }^{1}$, James A. Russell ${ }^{2}$, Keith R. Walley ${ }^{2}$, Joel Singer ${ }^{3}$, Dieter

Ayers $^{3}$, Michelle M. Storms ${ }^{2}$, Cheryl L. Holmes ${ }^{4}$, Paul C. Hébert ${ }^{5}$, D. James Cooper ${ }^{9}$, Sangeeta Mehta ${ }^{6}$, John T. Granton ${ }^{7}$, Deborah J. Cook ${ }^{8}$, Jeffrey J. Presneill ${ }^{10}$, for the Vasopressin and Septic Shock Trial (VASST) Investigators

From: 1. Imperial College NHS Trust, London, UK; 2. iCAPTURE centre, St Paul's Hospital, 3. Epidemiology and Biostatistics, St. Paul's Hospital, 4. Kelowna General Hospital, University of British Columbia; 5. Ottawa Hospital, General Campus University of Ottawa; 6. Mount Sinai Hospital, 7. Toronto General and Toronto Western Hospital, University of Toronto; 8. St. Joseph's Hospital, McMaster University, Canada; 9. Alfred Hospital, Monash University; 10. Royal Melbourne Hospital, University of Melbourne, Australia.

Address for correspondence and reprints:

Anthony C Gordon, MD, FRCA

Intensive Care Unit,

Charing Cross Hospital, Imperial College NHS Trust

Fulham Palace Road, London

W6 8RF, UK

Tel: $+44(0) 2083830657$

Fax: +44 (0)20 88461975

anthony.gordon@imperial.ac.uk

\section{Support:}


Canadian Institutes of Health Research, Grant number: MCT 44152

Registration: ISRCTN94845869, http://www.controlled-trials.com

Anthony C. Gordon is grateful for support from the NIHR Biomedical Research

Centre funding scheme. Keith R. Walley is a Michael Smith Foundation for Health

Research Distinguished Scholar. Deborah J. Cook is a Chair of the Canadian

Institutes of Health Research.

\section{Short title: VASOPRESSIN AND KIDNEY INJURY}

Title character and spaces count: 66

Abstract word count: 249

Word count: 2664 


\section{ABSTRACT}

Objective: To compare the effects of vasopressin versus norepinephrine infusion on the outcome of kidney injury in septic shock.

Design and Setting: Post-hoc analysis of the multi-centre double-blind randomized controlled trial of vasopressin versus norepinephrine in adult patients who had septic shock (VASST).

Patients and Intervention: 778 patients were randomized to receive a blinded infusion of either low-dose vasopressin $(0.01-0.03 \mathrm{U} / \mathrm{min})$ or norepinephrine infusion $(5-15 \mu \mathrm{g} / \mathrm{min})$ in addition to open-label vasopressors and were included in the outcome analysis. All vasopressors were titrated and weaned to maintain a target blood pressure.

Measurement and results: RIFLE criteria for acute kidney injury were used to compare the effects of vasopressin versus norepinephrine. In view of multiple simultaneous comparisons a p-value of 0.01 was considered statistically significant. Kidney injury was present in 464 patients $(59.6 \%)$ at study entry. In patients in the RIFLE “Risk” category $(\mathrm{n}=106)$ vasopressin as compared with norepinephrine was associated with a trend to a lower rate of progression to renal "Failure" or "Loss" categories $(20.8 \% \mathrm{v} 39.6 \%$ respectively, $\mathrm{p}=0.03)$, and a lower rate of use of renal replacement therapy $(17.0 \% \mathrm{v} 37.7 \%, \mathrm{p}=0.02)$. Mortality rates in the "Risk" category patients treated with vasopressin compared to norepinephrine were $30.8 \%$ v $54.7 \%$, $\mathrm{p}=0.01$, but this did not reach significance in a multiple logistic regression analysis $(\mathrm{OR}=0.33,99 \% \mathrm{CI} 0.10-1.09, \mathrm{p}=0.02)$. The interaction of treatment group and RIFLE category was significant in predicting mortality.

Conclusions: Vasopressin may reduce progression to renal failure and mortality in patients at risk of kidney injury who have septic shock.

Key words: Sepsis; kidney failure; vasopressins; shock, septic 


\section{INTRODUCTION}

Acute kidney injury is a common complication of sepsis that is associated with high mortality [1]. The incidence ranges from $15-50 \%$ [2-4], and is associated with a mortality rate of $30-75 \%$ [2-5]. This variation in reported incidence and outcome is partly due to heterogeneous patients and different definitions of kidney injury used in these studies. Recently, the acute dialysis quality initiative (ADQI) group recommended a consensus definition for kidney injury called the RIFLE criteria [6]. Patients are defined as being at "Risk" of kidney injury, having renal "Injury" or "Failure", having "Loss" of renal function or having "End-stage" renal failure based on decreased glomerular filtration rate (or increased serum creatinine) and urine output.

Despite the high prevalence of acute kidney injury during critical illness in general, and severe sepsis specifically, success has been limited in improving the outcome of this complication [7]. The mainstays of prevention and treatment include avoidance of nephrotoxins and ensuring adequate renal perfusion. In addition to its potent vasoconstrictor effects, vasopressin may also have specific beneficial effects on renal function secondary to its binding to a family of vasopressin receptors [8]. In several small studies of vasodilatory shock, vasopressin increased glomerular filtration rate, urine output and creatinine clearance [9-12]. However, to date no large studies have assessed the effect of vasopressin, as compared with norepinephrine, on the outcome of acute kidney injury.

Therefore, we studied patients who had septic shock recruited to the randomized controlled trial of vasopressin versus norepinephrine (VASST: Vasopressin and Septic Shock Trial) to compare the effects of vasopressin versus norepinephrine on 
the outcome of acute kidney injury using the RIFLE criteria. Some of this data has been presented in the form of an abstract at the American Thoracic Society International Conference, San Francisco, in 2007 [13]. 


\section{MATERIAL AND METHODS}

\section{Patients}

All patients $(n=779)$ randomized and infused with study drug from the VASST study were included. The study protocol has been previously described [14]. In summary, this was a multi-center randomized double-blind controlled trial of vasopressin versus norepinephrine in addition to standard vasopressors for the treatment of septic shock. Patients were greater than 16 years of age and had septic shock, defined by the presence of two or more of the systemic inflammatory response syndrome (SIRS) criteria [15], proven or suspected infection, new dysfunction of at least one organ, and hypotension despite adequate fluid resuscitation requiring vasopressor support of at least $5 \mu \mathrm{g} / \mathrm{min}$ of norepinephrine (or equivalent) for six hours. Important clinical exclusion criteria were unstable coronary syndromes, acute mesenteric ischemia, severe chronic heart disease (New York Heart Association class III and IV) and vasospastic diathesis [14]. Patients were randomized to receive a blinded infusion of study drug, either vasopressin $(0.01-0.03 \mathrm{U} / \mathrm{min})$ or norepinephrine $(5-15 \mu \mathrm{g} / \mathrm{min})$. The study drug and all other vasopressors were titrated and weaned according to protocols. The initial target mean arterial pressure was $65-75 \mathrm{mmHg}$. Other treatment decisions (including the need for renal replacement therapy) were at the local physician's discretion.

All patients were classified into one of the RIFLE categories at study baseline (see Table 1 for RIFLE classification definitions) based on the rise in serum creatinine measured at baseline (i.e., just prior to study drug infusion) compared to the patient's "normal" creatinine. For patients with known chronic renal failure their "normal" creatinine was taken as the lowest creatinine measured in the previous 24 hours. For 
patients without chronic renal failure the "normal" creatinine was taken as the lower of: the lowest creatinine measured in the previous 24 hours or the estimated creatinine calculated using the MDRD (Modification of Diet in Renal Disease) equation as in the original RIFLE description [6]. Patients without end-stage renal failure who were receiving renal replacement therapy at study baseline were assigned to the "Failure" category as previously described [16]. Patients with known end-stage kidney disease at study inclusion were classified as class "E" within RIFLE and were excluded from analyses of change in renal function. Details of fluid balance and diuretic therapy were available for the first four days of the study only. Data were not available to use the urine output criteria for the RIFLE definition.

\section{Statistics}

Outcome measures were 28-day mortality (the primary endpoint of the main trial), rate of progression to renal "Failure" / "Loss", the use of renal replacement therapy and serum creatinine over time up to day 28. Survival status at day 90 was also recorded. Comparison of outcome between the two treatment groups, vasopressin and norepinephrine patients, was performed using the chi-squared test. A multiple logistic regression model including age, sex, APACHE II score (measured in the 24 hours prior to study inclusion), medical / surgical admission, dose of norepinephrine at baseline and treatment group was used to adjust for possible imbalances at baseline between the two treatment groups within the patient subgroups in each RIFLE category. As the analyses were repeated in each of the five RIFLE classes at baseline a Bonferroni correction for multiple testing was applied and a p-value of 0.01 was considered statistically significant.

A linear mixed effects model was used to analyze longitudinal data (i.e., creatinine over time). Serum creatinine values were not normally distributed and so the values 
were $\log$ transformed for analysis. This analysis was also repeated adjusting for the dose of norepinephrine over time. A differential response to vasopressin compared to norepinephrine according to RIFLE category was tested using the interaction terms in the regression analyses. Other continuous variables are presented as mean $( \pm$ standard deviation) or median (interquartile range) and tested using the T-test, ANOVA or Mann Whitney U test, as appropriate. 


\section{RESULTS}

A total of 779 patients were randomized and infused with study drug, 397 with vasopressin, and 382 with norepinephrine. One patient in the vasopressin group was lost to follow up at day 28 and therefore only 778 patients were included in the outcome analysis. All patients had septic shock and at baseline required a mean norepinephrine dose of $20.7 \pm 20.2 \mu \mathrm{g} / \mathrm{min}$ to maintain a mean arterial pressure of $72.7 \pm 9.5 \mathrm{mmHg}$. The average baseline APACHE II score was $27.1 \pm 7.3$ and patients had $3.4 \pm 1.1$ organ failures, using the Brussels scoring system [17]. Full details of patient characteristics have previously been published [14].

We compared clinical outcomes between vasopressin-treated patients and norepinephrine-treated patients within each RIFLE category (Table 2). Within the "Risk" category, there was a trend for less patients to progress to renal "Failure" or "Loss" over the 28-day study period in the vasopressin-treated group than the norepinephrine group $(11[20.8 \%]$ v 21 [39.6\%] respectively, $\mathrm{p}=0.03)$. Within the "Risk" category, the use of renal replacement therapy at any time during the study period was less than half in the vasopressin group compared to the norepinephrine group $(9[17.0 \%]$ v $20[37.7 \%], p=0.02)$. There was no significant difference in progression of kidney injury between treatment groups in any other RIFLE category.

Serum creatinine decreased more in the "Risk" category of patients who were treated with vasopressin as compared with norepinephrine $(p=0.02)$ despite similar baseline creatinine values (Figure 2). This difference remained the same after adjusting for dose of norepinephrine $(p=0.02)$. There was no difference in serum creatinine over 
time between vasopressin and norepinephrine treated patients in any other RIFLE category (Figure 2). There was no significant difference in fluid input, fluid balance or diuretic use over the first four days between vasopressin and norepinephrine treated patients (data not shown).

We also compared 28-day mortality rates between vasopressin-treated patients and norepinephrine-treated patients within each RIFLE category (Table 2). Of those patients who were in the "Risk" category, mortality in the vasopressin-treated patients compared to norepinephrine-treated patients was 16/52 (30.8\%) versus 29/53 (54.7\%), $\mathrm{p}=0.01$. There were no significant differences in mortality between treatment groups in any other RIFLE category. The interaction of treatment group and RIFLE category ("Risk" versus "non-risk") for 28-day mortality rate was statistically significant ( $\mathrm{p}=$ 0.03). However, after adjusting for baseline characteristics (Table 3) using a logistic regression model, the odds ratio for mortality in patients randomized to receive vasopressin in the Risk category was not statistically significant $(\mathrm{OR}=0.33,99 \%$ confidence intervals $0.10-1.09, \mathrm{p}=0.02)$. The Kaplan-Meier survival curves demonstrate that the variation in mortality rates between vasopressin-treated and norepinephrine-treated patients began at about day 2 and then persisted throughout the full 90-day follow-up period $(\mathrm{p}=0.007, \log$ rank statistic) (Figure 1).

In the "Risk" category, vasopressin was associated with a significant decrease in norepinephrine infusion rate from a median of 20 (IQR 8 - 27) $\mu \mathrm{g} / \mathrm{min}$ to 9 (IQR 4 23.5) $\mu \mathrm{g} / \mathrm{min}$ and the total norepinephrine infusion rate remained lower in the vasopressin-treated group throughout the study (Figure 3, Panel A). This vasopressin infusion rate maintained mean arterial pressure at values similar to the mean arterial pressure in the norepinephrine-treated group (Figure 3, Panel B). 
Kidney injury (as defined by "Risk" category or worse) was present in 464 (59.6\%) of patients at baseline (Table 2) and was associated with significantly higher 28-day mortality than patients with no kidney injury $(44.3 \% \mathrm{v} 27.0 \%, \mathrm{p}<0.001)$. A further 117 patients who had "normal" renal function (non-AKI) at baseline had a deterioration in renal function so that in total, $581(74.6 \%)$ patients had kidney injury ("Risk" category or worse) at some time during the 28-day study period.

Excluding the 49 patients who had end-stage renal failure prior to inclusion, 532 of $730(72.9 \%)$ had acute kidney injury during the 28-day study period. Of these 730 patients, $247(33.8 \%)$ required renal replacement therapy. One hundred and fifty nine patients underwent continuous renal replacement therapy, 31 underwent intermittent hemodialysis and 57 underwent both types of replacement therapy. Nineteen $(4.1 \%)$ of the 466 survivors without pre-existing end-stage renal failure were still dependent on renal replacement therapy at day 28 . Of the 49 patients who had end-stage renal failure at baseline, 19 were managed with continuous renal replacement therapy, 8 with intermittent hemodialysis and 22 with both, during the study period. 


\section{DISCUSSION}

Comparison of vasopressin v norepinephrine

In this large multi-center study of patients who had septic shock, we found that acute kidney injury was very common, found in $73 \%$ of patients, and was associated with a high mortality rate. In patients who were at risk of kidney injury who had septic shock, we found that vasopressin compared to norepinephrine was associated with a trend to reduced creatinine over time, reduced progression to renal failure / loss and reduced mortality. As a result, fewer patients treated with vasopressin compared to norepinephrine required renal replacement therapy.

These results are consistent with previous small studies showing that vasopressin compared to norepinephrine increased urine output and creatinine clearance [9-12]. The findings in the "Risk" category contrast to those patients who had already sustained more severe kidney injury (RIFLE categories "Injury" or "Failure") at the time of study drug infusion; there was no difference in renal function or mortality according to vasopressin or norepinephrine allocation. Similarly, there was no significant beneficial effect of vasopressin in patients who had no acute kidney injury at baseline.

The interaction between treatment group and RIFLE category on mortality was significant, suggesting that the response to vasopressin treatment in the "Risk" category was significantly different to the response of patients in the other categories of RIFLE. These findings raise the possibility that patients classified in the RIFLE "Risk" category could be targeted for future therapeutic trials. 
Numerous studies have evaluated the RIFLE criteria in various critically ill populations [3, 16, 18-26]. The incidence of acute kidney injury varied between $11 \%$ and $67 \%$ in studies of general ICU patients $[16,18,20-22]$. To our knowledge, the current study is the largest study using RIFLE criteria in patients who have septic shock.

The $73 \%$ incidence of acute kidney injury in this cohort is slightly higher than in previous studies. However, this is not surprising, as we studied only severely ill patients who had septic shock. Previous studies have shown that the severity of sepsis correlates with the incidence of kidney injury [4]. The incidence of acute kidney injury we report is substantially higher than the incidence in the most severely ill patients described by Rangel-Frausto et al [4], which may reflect between study differences due to case mix, or a true increased incidence of acute kidney injury in sepsis today compared with the past, as has been suggested by others [20]. The high incidence we observed may also reflect greater sensitivity of the RIFLE definitions compared to older definitions of renal failure. In RIFLE, a rise in serum creatinine of only $50 \%$ from baseline is defined as "Risk" [6]. In agreement with previous studies examining outcomes using the RIFLE criteria [27, 28], we found that mortality was markedly higher among patients who were in the "Risk" category compared to patients with non-AKI at enrollment $(43 \%$ versus $27 \%, \mathrm{p}=0.002)$. Our study also suggests that patients in the RIFLE "Risk" category were indeed at increased risk of renal failure. Half of patients in the "Risk" category had deterioration in renal function. Interestingly, it was in the "Risk" subgroup of patients where a beneficial effect of vasopressin treatment was observed.

\section{Study limitations}


There are several limitations of this study. Although we used the consensus RIFLE definitions, like many other studies $[19,20]$ we were not able to asses the urine output criteria of the RIFLE definition; thus, the incidence of acute kidney injury using RIFLE may actually be higher than the $73 \%$ that we observed. Second, we did not examine the mechanisms of potential benefit of vasopressin in this study. Vasopressin has complex effects on renal function because of its global hemodynamic effects and because of its binding to the vasopressin family of receptors. The renal-specific effects of vasopressin include binding to AVPR1a receptors of glomerular efferent arterioles which causes glomerular efferent arteriolar vasoconstriction and thus increases glomerular filtration [29]. Furthermore vasopressin analogues have been shown to increase renal perfusion in decompensated liver cirrhosis [30] and are a standard of care in this condition. In contrast, norepinephrine binds to alpha-1 receptors of renal afferent arterioles and decreases glomerular perfusion pressure and filtration [31], although effects may vary between normal healthy states and sepsis [32]. Vasopressin-treated patients (Figure 3) had significantly lower norepinephrine infusion rates compared to the norepinephrine-treated patients. Mean arterial pressure was similar between the two treatment groups (Figure 3). Thus, differences between vasopressin and norepinephrine-treated patient outcomes may be due to beneficial effects of vasopressin or, alternatively, due to reduction in detrimental effects of norepinephrine.

Third, the findings of this post-hoc subgroup analysis should be interpreted cautiously [33] since they may represent a chance finding. Although we did correct for multiple comparisons some of the RIFLE categories are quite small and there were some imbalances in baseline characteristics. Adjusting for these baseline characteristics in a multiple logistic regression model resulted in the mortality rates within the "Risk" 
category no longer reaching statistical significance. However, the RIFLE criteria have been previously defined by an independent expert group [6] and have been well described in a number of other studies of critically patients [27]. Furthermore, the trend to a lower mortality rate in the vasopressin-treated patients at "Risk" of acute kidney injury was also accompanied by an improvement in renal function. This may provide a biologically plausible explanation for the finding of improved outcome associated with vasopressin treatment. This result is also consistent with the primary subgroup analysis of the VASST study in which vasopressin treatment was associated with decreased mortality in patients who had less severe shock and not in patients who had more severe shock [14].

Taken together, these data raise the hypothesis that if there is any benefit of treatment using vasopressin in septic shock, it may occur before significant organ failure is established. This hypothesis will need further testing. Strategies to improve the outcome of established renal failure have so far not provided any convincing benefit [34]. 


\section{CONCLUSION}

In a post hoc analysis of this large randomized controlled multicenter study, we found that vasopressin was associated with a trend to improved renal function, lower mortality and less renal replacement therapy in patients at "Risk" of acute kidney injury, but not in those who had already sustained significant renal injury. These results will need further testing in another randomized trial before adoption into routine clinical practice. 


\section{ACKOWLEDGEMENTS:}

In addition to the authors, the following persons and institutions participated in the VASST trial: Writing Committee: A.C. Gordon, J.A. Russell (chair), K.R. Walley, Holmes, J.T. Granton, P.C. Hebert, D.J. Cooper, S. Mehta, J. Singer, D.J. Cook, J.J. Presneill, M.M. Storms; Executive Committee - J.A. Russell (chair), K.R. Walley, C.L. Holmes, J.T. Granton, P.C. Hebert, D.J. Cooper, S. Mehta, J. Singer, A.C. Gordon, M.M. Storms (project coordinator), S. Jones (administrative assistant); Management Committee - - J.A. Russell (chair), M.M. Storms (project coordinator),

K.R. Walley, C.L. Holmes, J. Singer, A.C. Gordon, S. Jones (administrative assistant); DSMB - G.R. Bernard (chair), A.S. Slutsky, G.A Wells; CIHR - A. Gasparini; Data Management - J. Singer, B. Savage, D. Ayers, R. Woods, K. Wu, M. Maralit.

Dr Gordon had full access to all the data in the study and takes responsibility for the integrity of the data and the accuracy of the data analysis. 
VASST Clinical Centers:

Canada. British Columbia; St. Paul's Hospital; Vancouver General; Kelowna General Hospital; Richmond General Hospital; Royal Columbian. Manitoba; St. Boniface; Winnipeg Health Science Centre. Ontario; Ottawa Hospital, General Campus; UHN - Toronto General \& Toronto Western Hospitals; St. Joseph's Hospital; Mount Sinai Hospital; Ottawa Hospital, Civic Campus; St. Michael's; Sunnybrook and Women's College Health Science Centre; Hamilton Health Sciences Centre; London Health Sciences Centre; Sudbury Regional Hospital; Charles LeMoyne Hospital; Windsor - Hotel Dieu Hospital. Australia. Victoria; Alfred Hospital; Royal Melbourne; Monash Medical Center. Western Australia; Royal Perth Hospital. South Australia; Flinders Medical Centre. USA. Mayo Hospital. 


\section{REFERENCES}

1. Schrier RW, Wang W (2004) Acute renal failure and sepsis. N Engl J Med 351:159-169.

2. Hoste EA, Lameire NH, Vanholder RC, Benoit DD, Decruyenaere JM, Colardyn FA (2003) Acute renal failure in patients with sepsis in a surgical ICU: predictive factors, incidence, comorbidity, and outcome. J Am Soc Nephrol 14:10221030.

3. Lopes JA, Jorge S, Resina C, Santos C, Pereira A, Neves J, Antunes F, Prata MM (2007) Prognostic utility of RIFLE for acute renal failure in patients with sepsis. Crit Care 11:408.

4. Rangel-Frausto MS, Pittet D, Costigan M, Hwang T, Davis CS, Wenzel RP (1995) The natural history of the systemic inflammatory response syndrome (SIRS). A prospective study. Jama 273:117-123.

5. Neveu H, Kleinknecht D, Brivet F, Loirat P, Landais P (1996) Prognostic factors in acute renal failure due to sepsis. Results of a prospective multicentre study. The French Study Group on Acute Renal Failure. Nephrol Dial Transplant 11:293299.

6. Bellomo R, Ronco C, Kellum JA, Mehta RL, Palevsky P (2004) Acute renal failure - definition, outcome measures, animal models, fluid therapy and information technology needs: the Second International Consensus Conference of the Acute Dialysis Quality Initiative (ADQI) Group. Crit Care 8:R204-212.

7. Bellomo R, Chapman M, Finfer S, Hickling K, Myburgh J (2000) Low-dose dopamine in patients with early renal dysfunction: a placebo-controlled randomised trial. Australian and New Zealand Intensive Care Society (ANZICS) Clinical Trials Group. Lancet 356:2139-2143.

8. Barrett LK, Singer M, Clapp LH (2007) Vasopressin: mechanisms of action on the vasculature in health and in septic shock. Crit Care Med 35:33-40.

9. Landry DW, Levin HR, Gallant EM, Seo S, D'Alessandro D, Oz MC, Oliver JA (1997) Vasopressin pressor hypersensitivity in vasodilatory septic shock. Crit Care Med 25:1279-1282.

10. Holmes CL, Walley KR, Chittock DR, Lehman T, Russell JA (2001) The effects of vasopressin on hemodynamics and renal function in severe septic shock: a case series. Intensive Care Med 27:1416-1421. 
11. Patel BM, Chittock DR, Russell JA, Walley KR (2002) Beneficial effects of short-term vasopressin infusion during severe septic shock. Anesthesiology 96:576582.

12. Lauzier F, Levy B, Lamarre P, Lesur O (2006) Vasopressin or norepinephrine in early hyperdynamic septic shock: a randomized clinical trial. Intensive Care Med 32:1782-1789.

13. Gordon AC, Russell JA, Holmes Boulton CL, Singer J, Storms MM, Walley KR (2007) The effect of vasopressin on renal function in septic shock. Am J Respir Crit Care Med 175:A596.

14. Russell JA, Walley KR, Singer J, Gordon AC, Hebert PC, Cooper DJ, Holmes CL, Mehta S, Granton JT, Storms MM, Cook DJ, Presneill JJ, Ayers D (2008) Vasopressin versus norepinephrine infusion in patients with septic shock. N Engl J Med 358:877-887.

15. (1992) American College of Chest Physicians/Society of Critical Care Medicine Consensus Conference: definitions for sepsis and organ failure and guidelines for the use of innovative therapies in sepsis. Crit Care Med 20:864-874.

16. Ahlstrom A, Kuitunen A, Peltonen S, Hynninen M, Tallgren M, Aaltonen J, Pettila V (2006) Comparison of 2 acute renal failure severity scores to general scoring systems in the critically ill. Am J Kidney Dis 48:262-268.

17. Bernard G (1997) The Brussels Score. Sepsis 1:43-44.

18. Hoste EA, Clermont G, Kersten A, Venkataraman R, Angus DC, De Bacquer D, Kellum JA (2006) RIFLE criteria for acute kidney injury are associated with hospital mortality in critically ill patients: a cohort analysis. Crit Care 10:R73.

19. Uchino S, Bellomo R, Goldsmith D, Bates S, Ronco C (2006) An assessment of the RIFLE criteria for acute renal failure in hospitalized patients. Crit Care Med 34:1913-1917.

20. Ostermann M, Chang RW (2007) Acute kidney injury in the intensive care unit according to RIFLE. Crit Care Med 35:1837-1843;.

21. Bagshaw SM, George C, Dinu I, Bellomo R (2008) A Multi-Centre Evaluation of the Rifle Criteria for Early Acute Kidney Injury in Critically Ill Patients. Nephrol Dial Transplant 23:1203-1210.

22. Cruz DN, Bolgan I, Perazella MA, Bonello M, de Cal M, Corradi V, Polanco N, Ocampo C, Nalesso F, Piccinni P, Ronco C (2007) North East Italian Prospective 
Hospital Renal Outcome Survey on Acute Kidney Injury (NEiPHROS-AKI): targeting the problem with the RIFLE Criteria. Clin J Am Soc Nephrol 2:418-425. 23. Lopes JA, Jorge S, Silva S, de Almeida E, Abreu F, Martins C, do Carmo JA, Lacerda JF, Prata MM (2006) An assessment of the RIFLE criteria for acute renal failure following myeloablative autologous and allogeneic haematopoietic cell transplantation. Bone Marrow Transplant 38:395.

24. Lopes JA, Jorge S, Neves FC, Caneira M, da Costa AG, Ferreira AC, Prata MM (2007) An assessment of the RIFLE criteria for acute renal failure in severely burned patients. Nephrol Dial Transplant 22:285.

25. Lopes JA, Fernandes J, Jorge S, Neves J, Antunes F, Prata MM (2007) An assessment of the RIFLE criteria for acute renal failure in critically ill HIV-infected patients. Crit Care 11:401.

26. Kuitunen A, Vento A, Suojaranta-Ylinen R, Pettila V (2006) Acute renal failure after cardiac surgery: evaluation of the RIFLE classification. Ann Thorac Surg $81: 542-546$.

27. Ricci Z, Cruz D, Ronco C (2008) The RIFLE criteria and mortality in acute kidney injury: A systematic review. Kidney Int 73:538-546.

28. Joannidis M, Metnitz B, Bauer P, Schusterschitz N, Moreno R, Druml W, Metnitz PG (2009) Acute kidney injury in critically ill patients classified by AKIN versus RIFLE using the SAPS 3 database. Intensive Care Med:DOI 10.1007/s0013400009-01530-00134.

29. Edwards RM, Trizna W, Kinter LB (1989) Renal microvascular effects of vasopressin and vasopressin antagonists. Am J Physiol 256:F274-278.

30. Lenz K, Hortnagl H, Druml W, Reither H, Schmid R, Schneeweiss B, Laggner A, Grimm G, Gerbes AL (1991) Ornipressin in the treatment of functional renal failure in decompensated liver cirrhosis. Effects on renal hemodynamics and atrial natriuretic factor. Gastroenterology 101:1060-1067.

31. Bomzon L, Rosendorff C (1975) Renovascular resistance and noradrenaline. Am J Physiol 229:1649-1653.

32. Bellomo R, Kellum JA, Wisniewski SR, Pinsky MR (1999) Effects of norepinephrine on the renal vasculature in normal and endotoxemic dogs. Am J Respir Crit Care Med 159:1186-1192.

33. Assmann SF, Pocock SJ, Enos LE, Kasten LE (2000) Subgroup analysis and other (mis)uses of baseline data in clinical trials. Lancet 355:1064-1069. 
34. Palevsky PM, Zhang JH, O'Connor TZ, Chertow GM, Crowley ST, Choudhury D, Finkel K, Kellum JA, Paganini E, Schein RM, Smith MW, Swanson KM, Thompson BT, Vijayan A, Watnick S, Star RA, Peduzzi P (2008) Intensity of renal support in critically ill patients with acute kidney injury. N Engl J Med 359:7-20. 
Table 1. RIFLE criteria definitions used in this study [6]

\begin{tabular}{|l|l|}
\hline & Serum creatinine change criteria \\
\hline Risk & Increased serum creatinine $\mathrm{x} 1.5$ \\
\hline Injury & Increased serum creatinine $\mathrm{x} 2$ \\
\hline Failure & $\begin{array}{l}\text { Increased serum creatinine } \mathrm{x} 3 \mathrm{or} \\
\text { Increased serum creatinine } \geq 44 \mu \mathrm{mol} / \mathrm{l} \text { if } \\
\text { baseline } \geq 350 \mu \mathrm{mol} / \mathrm{l}\end{array}$ \\
\hline Loss & $\begin{array}{l}\text { Persistent acute renal failure }=\text { complete } \\
\text { loss of renal function for }>4 \text { weeks }\end{array}$ \\
\hline End stage & End-Stage Kidney Disease $(>3$ months $)$ \\
\hline
\end{tabular}

GFR $=$ Glomerular filtration rate. Serum creatinine $88 \mu \mathrm{mol} / 1=1 \mathrm{mg} / \mathrm{dl}$ 
Table 2. Baseline characteristics at time of study drug infusion, 28 day mortality rates and other outcomes according to RIFLE categories, and comparing the vasopressin and norepinephrine treatment groups according to RIFLE category.

\begin{tabular}{|c|c|c|c|c|c|c|c|c|}
\hline & \multicolumn{4}{|c|}{ Non-AKI } & \multicolumn{4}{|c|}{ Risk } \\
\hline & Total & NE & AVP & p-value ${ }^{\#}$ & Total & NE & AVP & p-value \\
\hline Number & $315(40.4)$ & 160 & 155 & & $106(13.6)$ & 53 & 53 & \\
\hline Age & $57.8 \pm 16.6$ & $59.8 \pm 16.7$ & $56.2 \pm 16.1$ & 0.06 & $61.2 \pm 16.8$ & $64.3 \pm 16.8$ & $58.1 \pm 16.4$ & 0.06 \\
\hline Sex - male & $203(64.4)$ & $101(63.1)$ & $102(65.8)$ & 0.70 & $69(65.1)$ & $37(69.8)$ & $32(60.4)$ & 0.42 \\
\hline APACHE II & $23.7 \pm 6.4$ & $24.5 \pm 6.0$ & $22.8 \pm 6.7$ & 0.007 & $27.0 \pm 6.2$ & $26.9 \pm 6.3$ & $27.0 \pm 6.2$ & 0.91 \\
\hline $\begin{array}{l}\text { Recent } \\
\text { Surgery }\end{array}$ & $120(41.7)$ & $62(38.8)$ & $58(37.4)$ & 0.81 & $38(38.0)$ & $16(30.2)$ & $22(41.5)$ & 0.22 \\
\hline $\begin{array}{l}\text { Ethnicity - } \\
\text { Caucasian }\end{array}$ & $266(84.4)$ & $134(83.8)$ & $132(85.2)$ & 0.73 & $92(86.8)$ & 47 (88.7) & $45(84.9)$ & 0.57 \\
\hline $\begin{array}{l}\text { Serum } \\
\text { creatinine at } \\
\text { enrollment } \\
(\mu \mathrm{mol} / \mathrm{l}) \\
\end{array}$ & $101 \pm 66$ & $100 \pm 64$ & $102 \pm 69$ & 0.73 & $154 \pm 34$ & $156 \pm 37$ & $152 \pm 30$ & 0.55 \\
\hline $\begin{array}{l}\text { Mean arterial } \\
\text { pressure at } \\
\text { baseline } \\
(\mathrm{mmHg})\end{array}$ & $74.3 \pm 8.4$ & $74.6 \pm 8.4$ & $74.1 \pm 8.4$ & 0.86 & $72.2 \pm 9.8$ & $72.9 \pm 10.4$ & $71.5 \pm 9.2$ & 0.49 \\
\hline
\end{tabular}




\begin{tabular}{|c|c|c|c|c|c|c|c|c|}
\hline $\begin{array}{l}\text { More severe } \\
\text { shock (NE } \\
>15 \mu \mathrm{g} / \mathrm{min}) \\
\end{array}$ & $131(41.6)$ & $72(45.0)$ & $59(38.1)$ & 0.26 & $66(62.3)$ & $33(62.3)$ & $33(62.3)$ & 1.0 \\
\hline $\begin{array}{l}\text { Cardiac Index } \\
\text { at baseline } \\
\left(\mathbf{l} / \mathbf{m i n} / \mathbf{m}^{2}\right)^{* *}\end{array}$ & $4.1 \pm 1.5$ & $4.0 \pm 1.4$ & $4.3 \pm 1.5$ & 0.43 & $3.6 \pm 1.3$ & $3.6 \pm 1.4$ & $3.5 \pm 1.3$ & 0.79 \\
\hline $\begin{array}{l}\text { Mechanically } \\
\text { ventilated at } \\
\text { inclusion }\end{array}$ & $301(95.6)$ & $157(98.1)$ & 144 (92.9) & 0.03 & $96(90.6)$ & 45 (84.9) & $51(96.2)$ & 0.05 \\
\hline $\begin{array}{l}\text { Comorbidities } \\
\text { Ischemic } \\
\text { heart disease }\end{array}$ & $45(14.3)$ & $25(15.6)$ & $20(12.9)$ & 0.49 & $15(14.2)$ & $8(15.1)$ & $7(13.2)$ & 0.78 \\
\hline $\begin{array}{l}\text { Congestive } \\
\text { heart failure }\end{array}$ & $20(6.3)$ & $13(8.1)$ & $7(4.5)$ & 0.19 & $7(6.6)$ & $4(7.5)$ & $3(5.7)$ & 0.70 \\
\hline Diabetes & $55(17.5)$ & $32(20.0)$ & $23(14.8)$ & 0.22 & $20(18.9)$ & $11(20.8)$ & $9(17.0)$ & 0.62 \\
\hline COPD & $65(20.6)$ & $38(23.8)$ & $27(17.4)$ & 0.16 & $14(13.2)$ & $8(15.1)$ & $6(11.3)$ & 0.57 \\
\hline $\begin{array}{l}\text { 28-day } \\
\text { mortality }\end{array}$ & $85(27.0)$ & $45(28.1)$ & $40(25.8)$ & 0.64 & $45(42.9)^{*}$ & $29(54.7)$ & $16(30.8)$ & 0.01 \\
\hline $\begin{array}{l}\text { Adjusted } \\
\text { OR } \\
(99 \% \text { CI }) \\
\end{array}$ & & & $\begin{array}{c}1.07 \\
(0.52-2.22)\end{array}$ & 0.81 & & & $\begin{array}{c}0.33 \\
(0.10-1.09)\end{array}$ & 0.02 \\
\hline $\begin{array}{l}\text { Need for RRT } \\
\text { during } 28-d a y \\
\text { study period }\end{array}$ & $36(11.4)$ & $20(12.5)$ & $16(10.3)$ & 0.54 & $29(27.4)$ & $20(37.7)$ & $9(17.0)$ & 0.02 \\
\hline $\begin{array}{l}\text { ICU length of } \\
\text { stay (days) }\end{array}$ & $18(10-36)$ & $18(11-33.5)$ & $17(9-37)$ & 0.73 & $14(6-26)$ & $14(4-26)$ & $14(11-25)$ & 0.60 \\
\hline
\end{tabular}




\begin{tabular}{|c|c|c|c|c|c|c|c|c|}
\hline & \multicolumn{4}{|c|}{ Injury } & \multicolumn{4}{|c|}{ Failure } \\
\hline & Total & $\mathbf{N E}$ & AVP & p-value ${ }^{\#}$ & Total & $\mathbf{N E}$ & AVP & p-value $\mathrm{e}^{\#}$ \\
\hline Number & $130(16.7)$ & 62 & 68 & & $179(23.0)$ & 82 & 97 & \\
\hline Age & $64.0 \pm 14.8$ & $64.8 \pm 13.6$ & $63.4 \pm 16.0$ & 0.63 & $61.9 \pm 16.4$ & $62.4 \pm 16.0$ & $61.5 \pm 16.7$ & 0.74 \\
\hline Sex - male & $75(57.7)$ & $32(51.6)$ & $43(63.2)$ & 0.25 & $99(55.3)$ & $43(52.4)$ & $56(57.7)$ & 0.58 \\
\hline APACHE II & $28.0 \pm 7.7$ & $27.1 \pm 6.4$ & $29.2 \pm 7.8$ & 0.06 & $31.3 \pm 6.5$ & $31.7 \pm 6.5$ & $31.1 \pm 6.5$ & 0.53 \\
\hline $\begin{array}{l}\text { Recent } \\
\text { Surgery }\end{array}$ & $49(41.5)$ & $20(32.3)$ & $29(42.6)$ & 0.22 & $62(35.6)$ & $25(30.5)$ & $37(38.1)$ & 0.28 \\
\hline $\begin{array}{l}\text { Ethnicity - } \\
\text { Caucasian }\end{array}$ & $113(86.9)$ & $51(82.3)$ & $62(91.2)$ & 0.28 & $147(82.1)$ & $66(80.5)$ & $81(83.5)$ & 0.60 \\
\hline $\begin{array}{l}\text { Serum } \\
\text { creatinine at } \\
\text { enrollment } \\
(\mu \mathrm{mol} / \mathrm{l})\end{array}$ & $205 \pm 39$ & $203 \pm 36$ & $207 \pm 42$ & 0.53 & $321 \pm 123$ & $333 \pm 135$ & $310 \pm 112$ & 0.21 \\
\hline $\begin{array}{l}\text { Mean arterial } \\
\text { pressure at } \\
\text { baseline } \\
(\mathrm{mmHg})\end{array}$ & $72.0 \pm 8.9$ & $72.9 \pm 8.2$ & $71.2 \pm 9.4$ & 0.28 & $71.6 \pm 11.4$ & $72.2 \pm 12.7$ & $71.0 \pm 10.2$ & 0.46 \\
\hline
\end{tabular}




\begin{tabular}{|c|c|c|c|c|c|c|c|c|}
\hline $\begin{array}{l}\text { More severe } \\
\text { shock (NE } \\
>15 \mu \mathrm{g} / \mathrm{min})\end{array}$ & 75 (57.7) & $35(56.5)$ & $40(58.8)$ & 0.92 & $105(58.7)$ & $47(57.3)$ & $58(59.8)$ & 0.86 \\
\hline $\begin{array}{l}\text { Cardiac Index } \\
\text { at baseline } \\
\left(\mathbf{l} / \mathbf{m i n} / \mathbf{m}^{2}\right)^{* *}\end{array}$ & $3.5 \pm 1.0$ & $3.9 \pm 1.1$ & $3.3 \pm 0.9$ & 0.19 & $4.1 \pm 1.3$ & $4.3 \pm 1.1$ & $4.0 \pm 1.3$ & 0.42 \\
\hline $\begin{array}{l}\text { Mechanically } \\
\text { ventilated at } \\
\text { inclusion }\end{array}$ & $118(90.8)$ & $54(87.1)$ & $64(94.1)$ & 0.17 & $169(94.4)$ & $81(98.8)$ & $88(90.7)$ & 0.02 \\
\hline $\begin{array}{l}\text { Comorbidities } \\
\text { Ischemic } \\
\text { heart disease }\end{array}$ & $28(21.5)$ & $11(17.7)$ & $17(25.0)$ & 0.31 & $35(19.6)$ & $15(18.3)$ & $20(20.6)$ & 0.69 \\
\hline $\begin{array}{l}\text { Congestive } \\
\text { heart failure }\end{array}$ & $12(9.2)$ & $5(8.1)$ & $7(10.3)$ & 0.66 & $13(7.3)$ & $5(6.1)$ & $8(8.2)$ & 0.58 \\
\hline Diabetes & $26(20.0)$ & $13(21.0)$ & $13(19.1)$ & 0.79 & $45(25.1)$ & $22(26.8)$ & $23(23.7)$ & 0.63 \\
\hline COPD & $11(8.5)$ & $6(9.7)$ & $5(7.4)$ & 0.63 & $31(17.3)$ & $18(22.0)$ & $13(13.4)$ & 0.13 \\
\hline $\begin{array}{l}\text { 28-day } \\
\text { mortality }\end{array}$ & $51(39.2)$ & $22(35.5)$ & $29(42.6)$ & 0.47 & $82(45.8)$ & 39 (47.6) & $43(44.3)$ & 0.67 \\
\hline $\begin{array}{l}\text { Adjusted } \\
\text { OR } \\
(99 \% \text { CI) }\end{array}$ & & & $\begin{array}{c}1.44 \\
(0.50-4.10)\end{array}$ & 0.37 & & & $\begin{array}{c}0.87 \\
(0.38-1.98)\end{array}$ & 0.67 \\
\hline $\begin{array}{l}\text { Need for RRT } \\
\text { during } 28 \text {-day } \\
\text { study period }\end{array}$ & $47(36.4)$ & $23(37.7)$ & $24(35.3)$ & 0.78 & $135(75.4)$ & $60(73.2)$ & $75(77.3)$ & 0.52 \\
\hline $\begin{array}{l}\text { ICU length of } \\
\text { stay (days) }\end{array}$ & $12(7-31)$ & $13(8-33)$ & $12(5-23.5)$ & 0.15 & $15(7-29.5)$ & $15(8-31)$ & $16(6-28)$ & 0.55 \\
\hline
\end{tabular}




\begin{tabular}{|c|c|c|c|c|c|}
\hline & \multicolumn{4}{|c|}{ End-stage } & \multirow[t]{2}{*}{$\begin{array}{c}\text { p-value } e^{\S} \\
\text { between RIFLE } \\
\text { categories }\end{array}$} \\
\hline & Total & NE & AVP & p-value ${ }^{\#}$ & \\
\hline Number & $49(6.3)$ & 25 & 24 & & \\
\hline Age & $62.3 \pm 13.3$ & $61.9 \pm 12.2$ & $62.6 \pm 14.7$ & 0.87 & 0.002 \\
\hline Sex - male & $29(59.2)$ & $16(64.0)$ & $13(54.2)$ & 0.68 & 0.25 \\
\hline APACHE II & $31.5 \pm 6.1$ & $30.1 \pm 6.4$ & $33.0 \pm 5.4$ & 0.09 & $<0.001$ \\
\hline Recent Surgery & $14(28.6)$ & $9(36.0)$ & $5(20.8)$ & 0.24 & 0.37 \\
\hline $\begin{array}{l}\text { Ethnicity - } \\
\text { Caucasian }\end{array}$ & $38(77.6)$ & $22(88.0)$ & $16(66.7)$ & 0.07 & 0.48 \\
\hline $\begin{array}{l}\text { Serum } \\
\text { creatinine at } \\
\text { enrollment } \\
(\mu \mathrm{mol} / \mathrm{l})\end{array}$ & $472 \pm 207$ & $463 \pm 181$ & $480 \pm 235$ & 0.78 & $<0.001$ \\
\hline $\begin{array}{l}\text { Mean arterial } \\
\text { pressure at } \\
\text { baseline } \\
(\mathrm{mmHg})\end{array}$ & $70.1 \pm 8.4$ & $69.1 \pm 10.2$ & $71.2 \pm 6.0$ & 0.40 & 0.002 \\
\hline
\end{tabular}




\begin{tabular}{|c|c|c|c|c|c|}
\hline $\begin{array}{l}\text { More severe } \\
\text { shock (NE } \\
>15 \mu \mathrm{g} / \mathrm{min})\end{array}$ & $24(49.0)$ & $13(52.0)$ & $11(45.8)$ & 0.88 & $<0.001$ \\
\hline $\begin{array}{l}\text { Cardiac Index } \\
\text { at baseline } \\
\left(1 / \mathrm{min} / \mathbf{m}^{2}\right)^{* *}\end{array}$ & $3.3 \pm 0.4$ & $3.4 \pm 0.5$ & $3.2 \pm 0.3$ & 0.48 & 0.10 \\
\hline $\begin{array}{l}\text { Mechanically } \\
\text { ventilated at } \\
\text { inclusion }\end{array}$ & $45(91.8)$ & $23(92.0)$ & $22(91.7)$ & 0.97 & 0.21 \\
\hline $\begin{array}{l}\text { Comorbidities } \\
\text { Ischemic } \\
\text { heart disease }\end{array}$ & $10(20.4)$ & $6(24.0)$ & $4(16.7)$ & 0.52 & 0.29 \\
\hline $\begin{array}{l}\text { Congestive } \\
\text { heart failure }\end{array}$ & $6(12.2)$ & $3(12.0)$ & $3(12.5)$ & 0.96 & 0.60 \\
\hline Diabetes & $19(38.8)$ & $10(40.0)$ & $9(37.5)$ & 0.86 & 0.03 \\
\hline COPD & $6(12.2)$ & $2(8.0)$ & $4(16.7)$ & 0.14 & 0.01 \\
\hline $\begin{array}{l}\text { 28-day } \\
\text { mortality }\end{array}$ & $27(55.1)$ & $15(60.0)$ & $12(50.0)$ & 0.48 & $<0.001$ \\
\hline $\begin{array}{l}\text { Adjusted OR }{ }^{\# \#} \\
(99 \% \text { CI })\end{array}$ & & & $\begin{array}{c}0.67 \\
(0.13-3.47) \\
\end{array}$ & 0.53 & \\
\hline $\begin{array}{l}\text { Need for RRT } \\
\text { during } 28 \text {-day } \\
\text { study period }\end{array}$ & $49(100)$ & $25(100)$ & $24(100)$ & - & $<0.001$ \\
\hline $\begin{array}{l}\text { ICU length of } \\
\text { stay (days) }\end{array}$ & $15.5(7-27.5)$ & $14(2-25.5)$ & $20(7.5-48.5)$ & 0.25 & 0.006 \\
\hline
\end{tabular}


Values are numbers $(\%)$ or mean $\pm \mathrm{SD}$ or median $\left(25-75^{\text {th }}\right.$ centiles $)$. Patients" "normal" creatinine was estimated in $394 / 779(50.6 \%)$ of cases for RIFLE classification. *One patient in the "Risk" group was lost to follow up and therefore not included in the mortality analysis. **Cardiac index was measured in a subset of 153 patients at baseline. ${ }^{\#}$-values compares variable between NE and AVP group within RIFLE category. ${ }^{\text {\# }}$

Adjusted OR refers to multivariate logistic regression model of 28-day mortality rates. ${ }^{\$}$ Compares variable between RIFLE categories in all patients. $\mathrm{RRT}=$ renal replacement therapy, $\mathrm{NE}=$ norepinephrine, $\mathrm{AVP}=$ vasopressin. 
Table 3. Multivariate logistic regression model for 28-day mortality in "Risk" category patients

\begin{tabular}{|l|c|c|c|c|}
\hline & Odds ratio & \multicolumn{2}{|c|}{$99 \%$ CI } & p-value \\
\hline Age & 1.01 & 0.97 & 1.06 & 0.38 \\
\hline Male sex & 0.87 & 0.24 & 3.14 & 0.87 \\
\hline APACHE II & 1.04 & 0.94 & 1.16 & 0.31 \\
\hline $\begin{array}{l}\text { Surgical } \\
\text { admission }\end{array}$ & 0.61 & 0.18 & 2.08 & 0.30 \\
\hline $\begin{array}{l}\text { Dose of NE at } \\
\text { baseline }\end{array}$ & 1.03 & 1.00 & 1.06 & 0.02 \\
\hline $\begin{array}{l}\text { Vasopressin } \\
\text { treatment }\end{array}$ & 0.33 & 0.10 & 1.09 & 0.02 \\
\hline
\end{tabular}

$\mathrm{NE}=$ norepinephrine. For the continuous variables the odds ratio refers to each year of age, each point of APACHE II score, and each $\mu \mathrm{g} / \mathrm{min}$ of norepinephrine. For dichotomous variables comparison references are male $\mathrm{v}$ female sex, surgical $\mathrm{v}$ medical admission, and vasopressin $\mathrm{v}$ norepinephrine treatment allocation. 


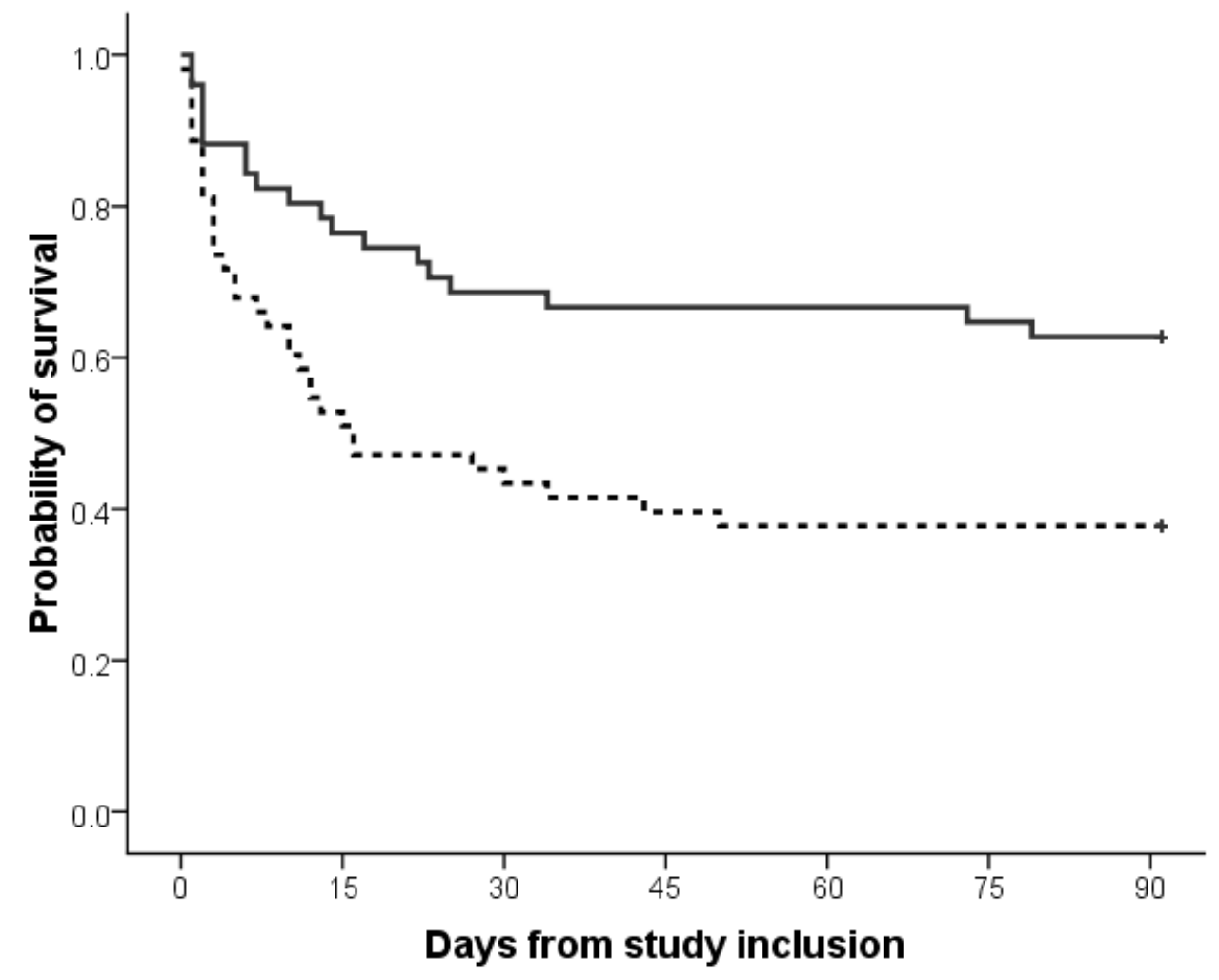

Figure 1. Kaplan Meier survival curves for at "Risk" patients in the vasopressintreated group, solid black line, and the norepinephrine-treated group, dotted line $(\mathrm{p}=$ 0.007). $\mathrm{P}$ value was calculated using the log rank statistic. 
A

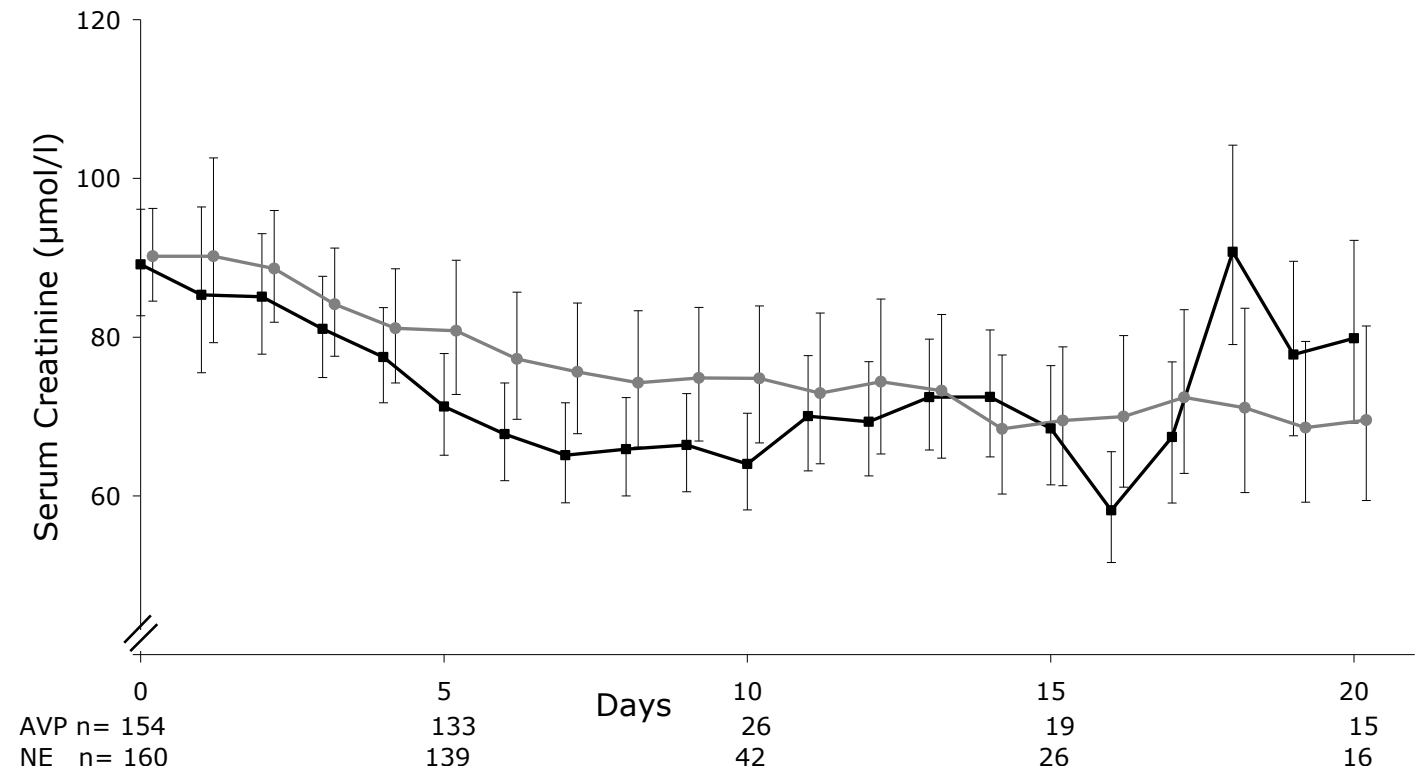

B

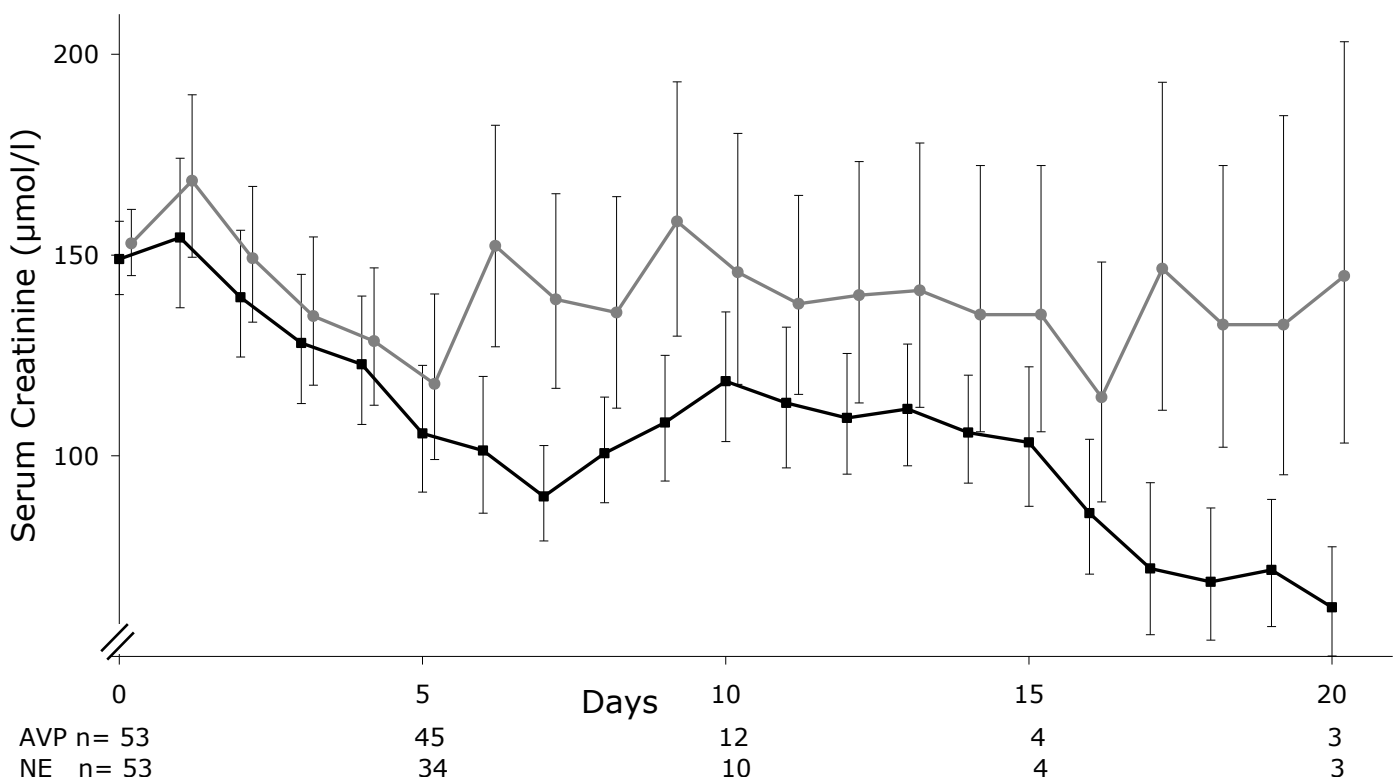


$\mathrm{C}$

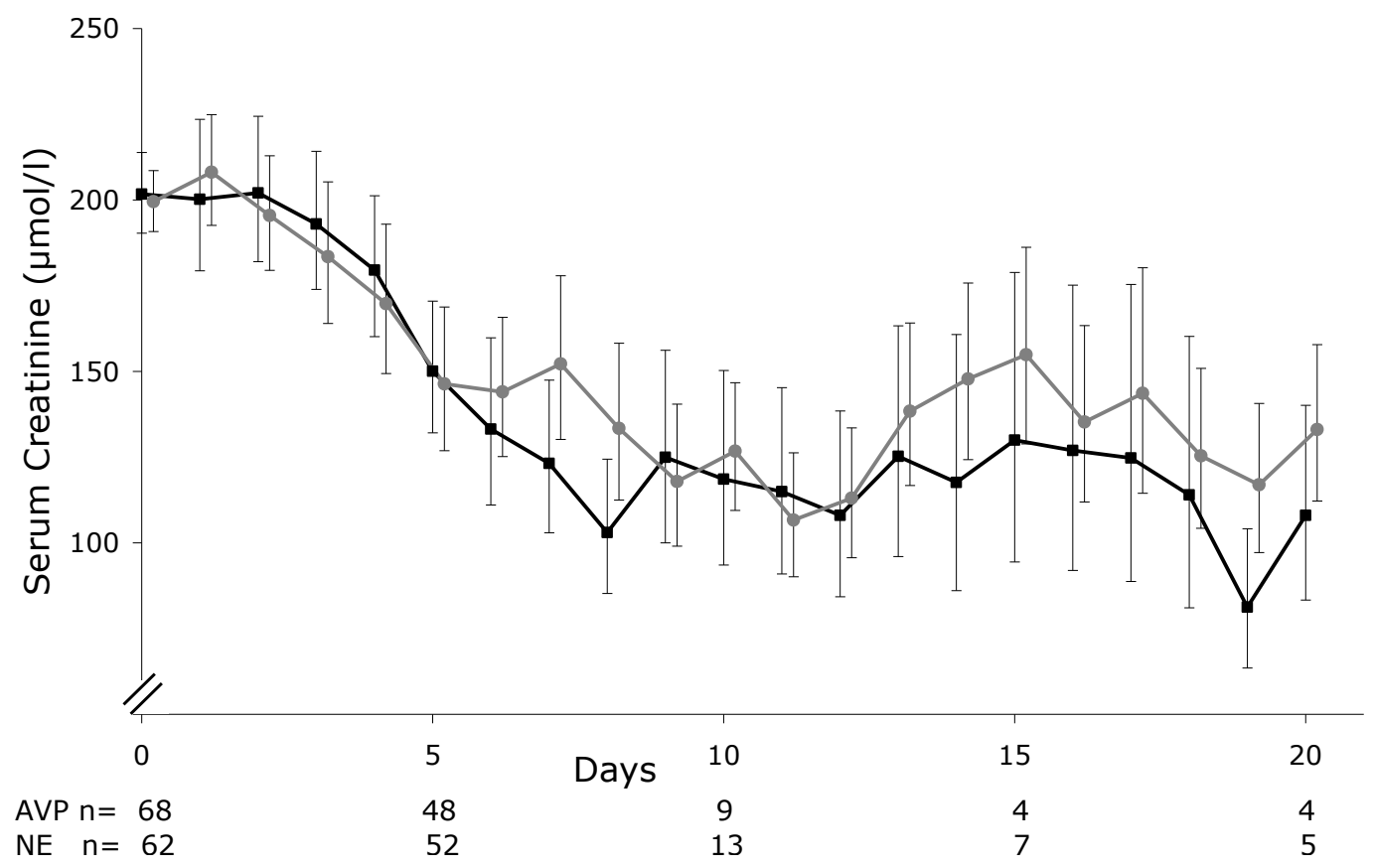

$\mathrm{D}$

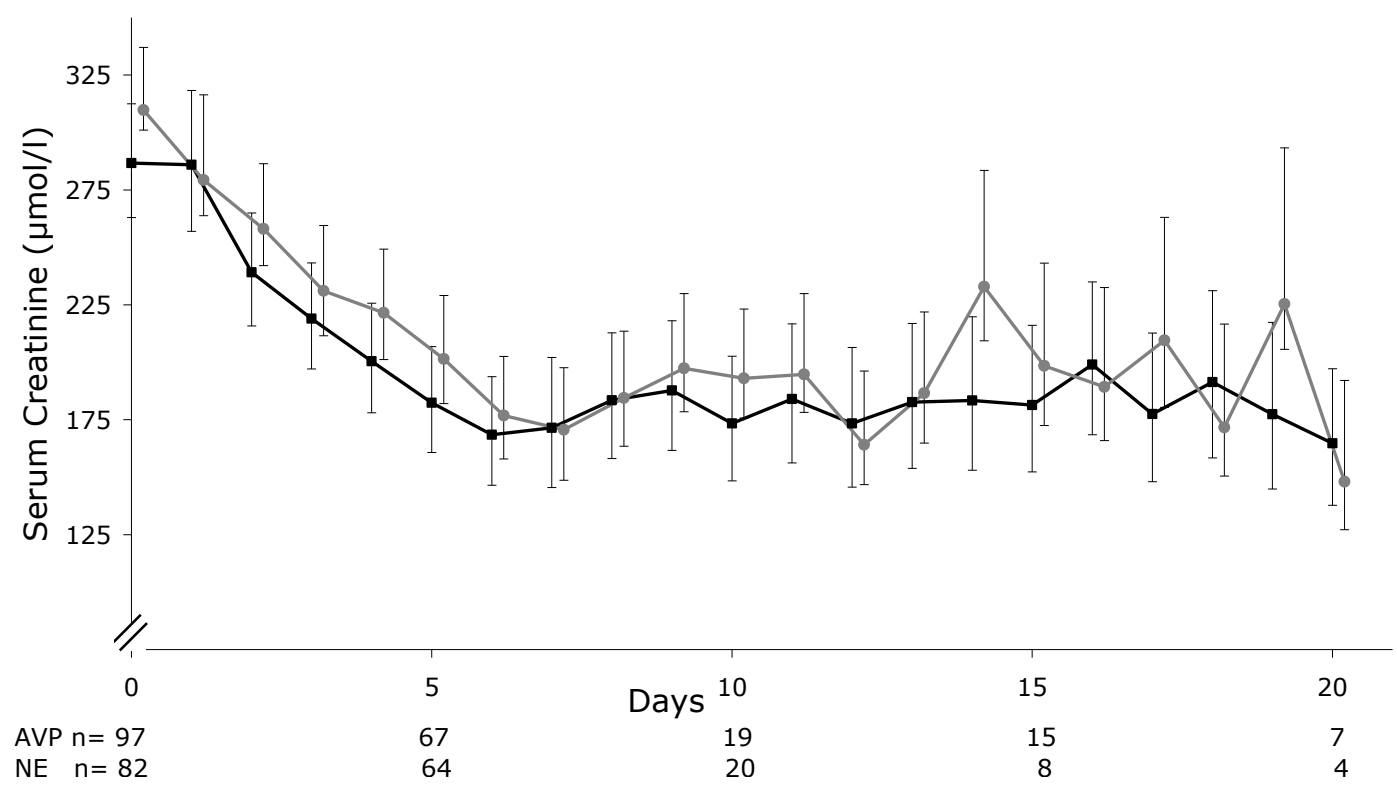

Figure 2. Mean serum creatinine (and 95\%CI) over the first 20 days from start of study drug infusion in A - "Non-AKI" category, B - "Risk" category, C - "Injury" category, D - "Failure" category of RIFLE. Grey circles represent norepinephrine group, black squares represent vasopressin group. Serum creatinine values recorded whilst receiving renal replacement therapy have been excluded from the analysis. 
Data after day 20 has not been shown due to small numbers in each group. AVP = vasopressin, $\mathrm{NE}=$ norepinephrine 
A.

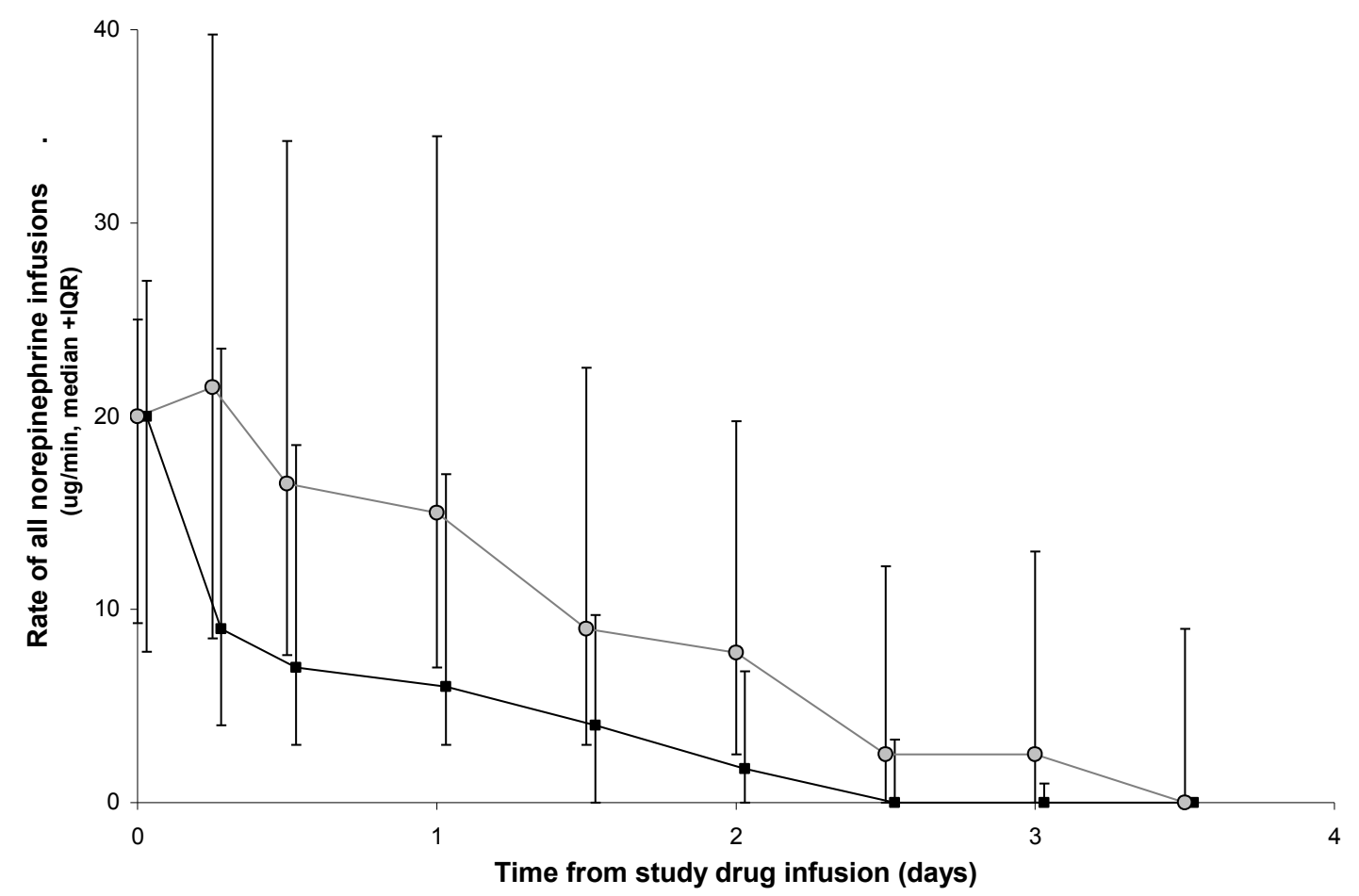

B.

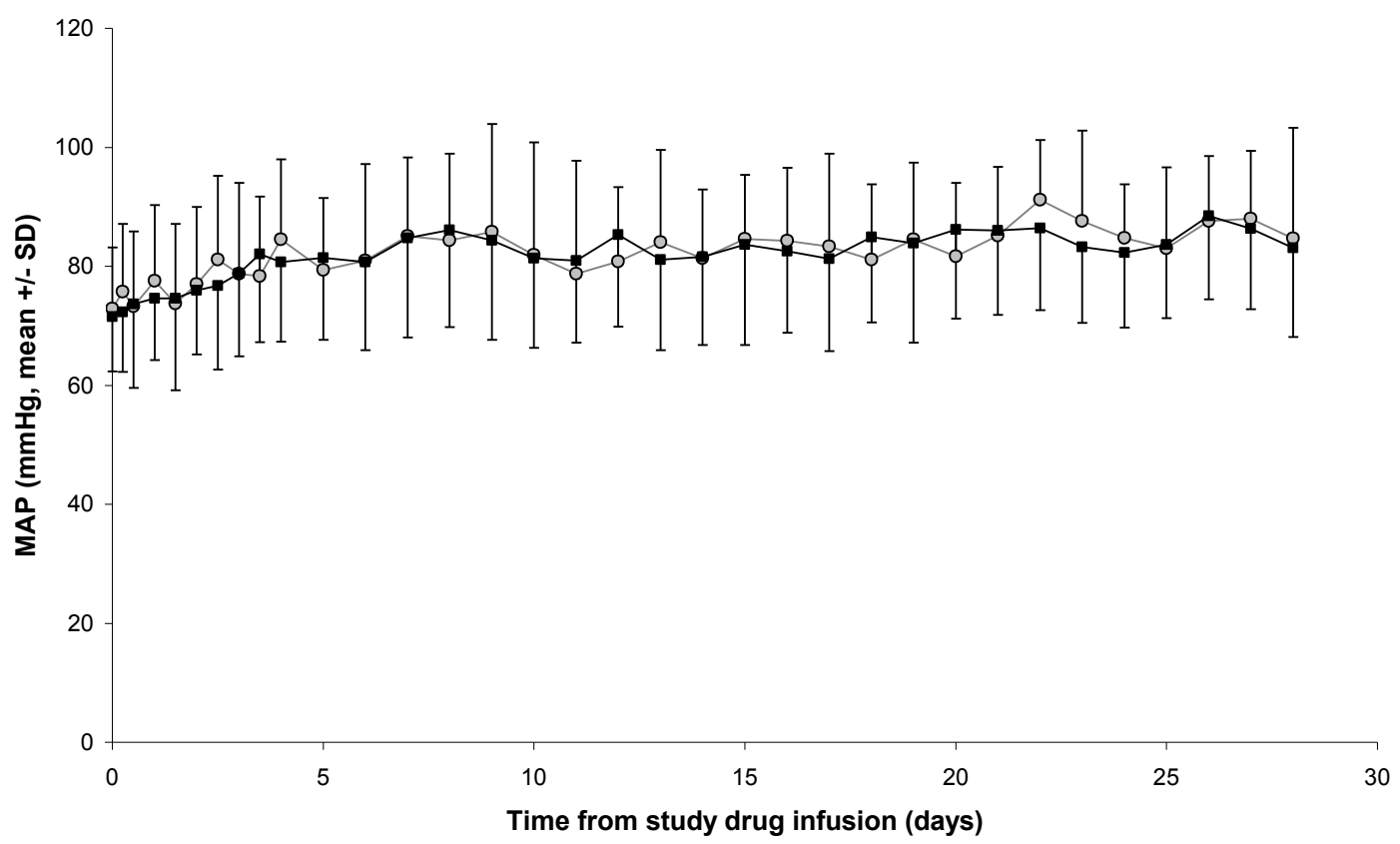

Figure 3. Median $( \pm \mathrm{IQR})$ norepinephrine infusion rates are shown (Panel A) for patients receiving open-label norepinephrine at baseline in vasopressin and in norepinephrine treatment groups of patients in VASST who were in the "Risk" category of acute kidney injury according to RIFLE. Vasopressin-treated patients (black squares) had significantly reduced norepinephrine infusion rates compared to 
the norepinephrine-treated patients (grey circles) $(\mathrm{p}<0.001)$. Mean arterial pressure was similar between the two treatment groups (Panel B). 